\title{
Aspekt som analytisk tilnarming til utforskende elevtekster
}

\author{
Sindre Dagsland* \\ NTNU, Norges teknisk-naturvitenskaplige universitet
}

\begin{abstract}
Sammendrag
Når elever blir bedt om å utforske noe i en skriveoppgave kommer det til syne en spenning mellom det utforskende som prosess eller produkt: En utforskende tekst (som tekstlig produkt) og en utforskende aktivitet (prosess) er ikke nødvendigvis det samme. Artikkelen undersøker hvordan denne spenningen kan belyses gjennom det språklige fenomenet «aspekt». Aspektbegrepet handler om hvordan handlinger og prosesser kan ses på som avsluttede (perfektive) eller vedvarende (imperfektive), og artikkelen undersøker hvordan elever posisjonerer seg i etterkant av avsluttede eller som del av vedvarende utforskingsprosesser i tekstene de skriver. Gjennom aspektanalyse av tre elevtekster skrevet i matematikkfaget belyses det problematiske ved forståelsen av Skrivehjulets skrivehandling «å utforske», og hvordan aspekt kan være en nyttig inngang til å forstå hva det å utforske kan innebære i skriving. Det teoretiske grunnlaget i artikkelen utvider forståelsen av aspektkategorien fra en lokalsemantisk til en kontekstuell forståelse. Artikkelen har dermed to hovedanliggender: Å utvikle en analytisk tilnærming basert på det språklige fenomenet «aspekt» som relevant inngang for analyse av elevtekster, og å diskutere utfordringer ved utforskingsbegrepet i modellen Skrivehjulet.
\end{abstract}

Nøkkelord: Skriveforskning; posisjonering; relieff; skriving som grunnleggende ferdighet; literacy; skriving i matematikk

\begin{abstract}
When pupils are asked to explore something in writing, a tension between exploration as a product or a process emerges: An explorative text (product) and an explorative activity (process) isn't necessarily the same thing. The article explores a claim that this tension can be shed light on through the linguistic term 'aspect'. The concept of aspect regards how acts and processes are interpreted as completed (perfective) or ongoing (imperfective), and the article explores how pupils position themselves as part of completed or ongoing explorative processes in their texts. Through an aspectual approach to three pupils' texts, the article sheds light on challenges regarding The Wheel of Writing's act of writing 'to explore' and shows how aspect can be a useful approach to the understanding of what explorative writing can be. The theoretical grounding of the article expands the understanding of aspect from a local-semantic to a contextual one. Thus, the article has two main goals: to develop an analytical approach to pupils' texts based on the linguistic term aspect, and to discuss challenges and tensions related to the concept of exploration in the model The Wheel of Writing.
\end{abstract}

\footnotetext{
^Korrespondanse: Sindre Dagsland, Epost: sindre.dagsland@ntnu.no

(C) 2019 S. Dagsland. This is an Open Access article distributed under the terms of the Creative Commons Attribution 4.0 International License (https://creativecommons.org/licenses/by-nc/4.0/), allowing third parties to copy and redistribute the material in any medium or format and to remix, transform, and build upon the material for any purpose, even commercially, provided the original work is properly cited and states its license. 


\section{S. Dagsland}

Keywords: Writing research; positioning; grounding; writing as a key competence; literacy; writing in mathematics

Responsible editor: Per Henning Uppstad

Recieved: November, 2018; Accepted: June, 2019; Published: October, 2019

\section{Aspekt som analytisk tilnæerming til utforskende elevtekster}

Hva innebærer det å utforske noe gjennom skriving? Når elever blir bedt om å utforske noe i en skriveoppgave kommer det til syne en spenning mellom det utforskende som prosess eller produkt: En utforskende tekst (produkt) og en utforskende aktivitet (prosess) er ikke nødvendigvis det samme, og det er ikke gitt at en intendert utforskende skriveoppgave genererer utforskende tekster (Dagsland, 2018). I denne artikkelen hevder jeg at begrepet aspekt kan være en nyttig inngang for oss skriveforskere til å forstå hva det å utforske kan innebære i skriving, og være med på å konkretisere dimensjoner ved utforskingsbegrepet overfor lærere og elever.

I grammatisk terminologi står begrepet aspekt for handlingers avsluttethet, det vil si om en handling, prosess eller tilstand ses på som avsluttet (perfektiv) eller vedvarende (imperfektiv) (Givón, 1993; Hopper, 1982). Hovedgrunnen til å undersøke aspekt i elevtekster er at prosessers avsluttethet eller vedvarenhet står i relasjon til spenningen mellom det å utforske som produkt eller prosess. Hvis man i en tekst skriver om en utforskende aktivitet som allerede har skjedd, der verbalformen avslører at utforskingsprosessen ses på som avsluttet (perfektiv), er kanskje teksten (som produkt) heller beskrivende fremfor utforskende. Aspektperspektivet er lite utforsket i forbindelse med elevers skriving - både i Norge og internasjonalt, kanskje fordi forskning på aspekt oftest tolker aspekt isolert i relasjon til setningen verbalformen er en del av, dvs. på det lokalsemantiske nivået (i f.eks. Tonne, 2011). I denne artikkelen danner dialogisk ytringsteori (Bakhtin, 1995, 2005) og pragmatisk orientert aspektteori (Hopper, 1982) et forståelsesgrunnlag som åpner opp for at aspekt også kan forstås dialogisk og kontekstuelt. Målet er å vise hvorfor og hvordan en slik aspektforståelse har relevans for skriveforskeres så vel som læreres arbeid med elevtekster, spesielt når oppgaveformuleringen ber elevene om å utforske noe gjennom skriving.

Artikkelen bygger på både teori og empiriske eksempler. De tre elevtekstene og de to skriveoppgavene jeg skal se nærmere på, er eksempler på skriving der 7. trinnselever blir bedt om å utforske noe i matematikkfaget. Elevtekstene er skrevet som del av intervensjonsprosjektet Developing national standards for the assessment of writing. A tool for teaching and learning "Normprosjektet», (Berge et al. (2017)). I dette prosjektet måtte de deltakende lærerne utforme skriveoppgaver ut fra modellen Skrivehjulet (se vedlegg 1). Kort sagt er det en modell som skal representere det vi bruker skrift til generelt i verden (Evensen, 2010), og den består av seks skrivehandlinger som er koblet til ulike formål for skrivingen (Berge, Evensen \& Thygesen, 2016; Solheim \& Matre, 2014). Én av de seks skrivehandlingene er det «å utforske». Etter 
innledningen belyses dimensjoner ved denne modellen, og spesielt fokuserer jeg på utforskingsbegrepet i modellen. Det er i denne forbindelse jeg kommer frem til den nevnte spenningen mellom det å utforske som prosess og som produkt i Skrivehjulets utforskingsbegrep. Aspektbegrepet utvikler jeg teoretisk ved hjelp av nevnte Hopper (1982) og Bakhtin (1995; 2005). De empiriske eksemplene brukes som del av et analytisk resonnement om hvordan aspekt kommer til uttrykk i elevtekster når et dialogisk og kontekstuelt perspektiv legges til grunn. Analysetilnærmingen er en kombinasjon av posisjoneringsanalyse og relieffanalyse (Dagsland, 2018), spesielt med hensyn til aspekt, og elevteksteksemplene illustrerer analytiske og teoretiske poenger om aspekt og utfordringer ved utforskingsbegrepet. Avslutningsvis i artikkelen skal jeg, med bakgrunn i teksteksemplene, oppsummere og drøfte hvordan tilnærmingen til aspekt bidrar med en problematisering og konkretisering av utforskingsbegrepet, både når det gjelder Skrivehjulets skrivehandling, (intendert) utforskende oppgaveformuleringer og (antatt) utforskende elevtekster. I lys av artikkelens teoretiske aspektblikk går det nemlig an å diskutere om enkelte av tekstene kan kalles utforskende, eller om noen av dem kanskje heller bør betegnes som noe annet. ${ }^{1}$

Skriveoppgavene og elevtekstene jeg trekker fram i artikkelen er en del av empirien i min avhandling (Dagsland, 2018), og er valgt ut fra et materiale på 203 elevtekster. Tekstene illustrerer teoretiske poenger som er interessante for en aspekttilnærming, og de er også gode eksempler på aspektmønstre i det totale materialet. Jeg fulgte en klasse ved én av de 20 deltakende skolene i Normprosjektet gjennom ett år på skolen (fra slutten av 6. trinn til slutten av 7. trinn). De to skrivehandlingene "å reflektere» og «å utforske» ble tematisert og gjort eksplisitte i klasserommet, i fagene norsk og matematikk, og de 34 elevene skulle skrive åtte tekster hver (to refleksjonstekster i matematikk og to i norsk, to utforskingstekster i matematikk og to i norsk). ${ }^{2}$ Skriftlige tekster (de 203 tekstene), intervjuer med elever og lærere (der vi snakket om elevtekstene), observasjoner og lydopptak ble samlet inn i forbindelse med åtte skrivehendelser. Empirien som trekkes frem i denne artikkelen utgjøres av to av de åtte skriveoppgavene som ble gitt og tre elevtekster skrevet av elevene "Morten", "Mia" og "Petter". I tillegg trekker jeg enkelte steder inn elementer fra intervjuer med elevene.

\section{Skrivehjulet og utforskende skriving: en spenning mellom produkt og prosess}

Mieke Bal (2002) skriver i boken Travelling concepts in the humanities om hva som kjennetegner begrepet begrep, og trekker spesielt fram at begreper er vandrende og i bevegelse (jf. boktittelen). Hvordan vi bruker begrepene har betydning for hva et begrep innebærer, noe som innebærer at begreper ikke er uttrykk for statiske

\footnotetext{
${ }^{1}$ I Dagsland (2015) problematiserer jeg refleksjonsbegrepet i Skrivehjulet, mens denne artikkelen er en kritisk drøfting av utforskingsbegrepet i samme modell. Artiklene kan leses sammen på den måten at de begge bygger på samme avhandlingsarbeid (Dagsland, 2018) og fordi de sammen setter lys på noen viktige utfordringer og spenninger når det kommer til skriving ut fra Skrivehjulets skrivehandlinger. ${ }^{2}$ I det totale utvalget på 203 tekster er ikke alle de 34 elevene i klassen inkludert. Noen elevers foreldre takket nei til å delta, og noen elever fikk av ulike grunner ikke skrevet svar på samtlige åtte skriveoppgaver.
} 


\section{S. Dagsland}

størrelser (Bal, 2002). Overført til utforskingsbegrepet betyr dette at vårt «utforskingssnakk», hvordan vi snakker om og bruker ord som utforsking, å utforske, osv., gjør noe med hva begrepet kan innebære fra situasjon til situasjon. Ord og fraser som involverer ordet utforsking (utforskende skriving, utforskende arbeidsmåter, osv.) er utbredt i skolen på tvers av fag, og i Bals «vandrende» perspektiv er det ikke slik at dette nødvendigvis innebærer helt det samme utforskingsbegrepet. For eksempel er utforskingsbegrep sentralt i naturfags- og matematikkdidaktikk (ofte også betegnet gjennom begrepet inquiry - jf. f.eks. Kolstø og Knain (2011)), der det å utforske omtales som ulike former for utforskende prosesser der elevenes hypoteser og spørsmål skal være drivende for utforskingen som prosess. I Utforsking $i$ alle fag (Bjørshol \& Nolet, 2017) blir det også lagt vekt på utforsking som prosess, og spesielt blir utforsking satt i sammenheng med «utforskende aktiviteter», "utforskende metode» og «utforskende arbeidsmåter» i ulike fag. Skrivesenteret (som henviser til Dysthe, Hoel og Hertzberg (2010)) kobler «utforskende skriving» sammen med et refleksjons- og tenkebegrep. Dysthe et al. (2010) skriver at: «Utforskende, utprøvende skriving ligger nær opp til talespråket. Den er ofte springende, fragmentarisk og uoversiktlig fordi den gjerne følger tankes løp» (Dysthe et al., 2010, s. 67). Dette representerer et kognitivt orientert utforskingsbegrep der utforskende skriving kobles til en tankeprosess som skal: "[g]i elevene frirom til refleksjon og utforskende tenkning» (Hertzberg, 2011, s. 12). Dette er en litt annen måte å forstå utforskingsbegrepet på enn det å omtale det å utforske som en skrivehandling.

I konteksten som artikkelens empiriske eksempler er hentet fra (Normprosjektet), ble det å utforske definert som én av seks skrivehandlinger i modellen Skrivehjulet. Dette får betydning for hvordan utforskingsbegrepet kan forstås i denne konkrete sammenhengen. Selv om artikkelformatet ikke gir rom for å gi en uttømmende presentasjon av Skrivehjulet, vil jeg komme inn på dimensjoner ved modellen som er relevant for diskusjonen videre. Spesielt vil jeg trekke inn dimensjoner som er relevant for mitt fokus på utforskingsbegrepet i en aspekt-sammenheng. ${ }^{3}$

Skrivehjulet er "en slags generalisering over alt vi kan bruke skriving til», skriver Berge (2006). Skrivehjulet består av seks skrivehandlinger som er koblet til ulike formål for skrivingen (Solheim \& Matre, 2014; Berge et al., 2016). De seks skrivehandlingene er å reflektere, å utforske, å beskrive, å samhandle, å overbevise og å forestille seg. Disse er i modellen koblet til seks skriveformål: identitetsdanning, kunnskapsutvikling, kunnskapsorganisering, utveksling av informasjon, påvirkning og konstruksjon av tekstverdener. Modellen er ment å være dynamisk, det vil si at hjulet kan dreies slik at ulike skrivehandlinger kan kombineres med ulike formål, i tillegg til at flere skrivehandlinger kan finnes i samme tekst.

Det som skiller Skrivehjulets «å utforske» fra andre måter å bruke et utforskings- og inquirybegrep, er implikasjonene av at det å utforske defineres som en skrivehandling. Til forskjell fra IEA-undersøkelsens skrivekonstrukt (Gorman, Purves \& Degenhart,

${ }^{3}$ For en mer uttømmende presentasjon av Skrivehjulet, se Berge et al. (2016), og for en grundigere problematisering av modellen, se Dagsland (2018). 
1988), som legger vekt på at tekster skal representere en kognitiv tilstand, trekker Berge et al. (2016) fram at Skrivehjulet heller innebærer et fokus på tekstlige egenskaper $i$ teksten som produkt. For utforskingsbegrepets del betyr dette at utforskingen skriftliggjøres i Skrivehjulet gjennom at det å utforske er noe man gjør språklig i ytringen, fremfor å omtale det å utforske som en taktil, romlig eller kognitiv utforsking (som i eksemplene ovenfor). Dette innebærer at utforsking ikke er å forstå som noe som skjer kognitivt mens man skriver, eller forstås som en romlig eller taktil utforskingsprosess, men at utforsking er en skriftlig handling som skjer i teksten som produkt. ${ }^{4}$

Skrivehjulets skrivehandlinger og skriveformål er ment å være relevante på tvers av fag (Evensen, 2010; Solheim \& Matre, 2014), og Skrivehjulet er åpent med hensyn til hva som er og kan være utforskende skriving i ulike kontekster. Modellen er idealtypisk $k^{5}$ og er ikke ment å svare på hva de ulike skrivehandlingene empirisk "er» eller "ser ut som». Som idealtyper vil skrivehandlingene aldri finnes i «ren form» i virkeligheten, og dette gjør det utfordrende og komplekst å nærme seg spørsmål om hva skriving og oppgavelaging ut fra de ulike skrivehandlingene kan innebære.

I Normprosjektet måtte Skrivehjulet brukes av de deltakende lærerne som et utgangspunkt for å utforme skriveoppgaver i ulike fag (Berge, 2006; Solheim \& Matre, 2014, s. 81-82). Sagt på en annen måte: Elevene skrev tekster med utgangspunkt i skriveoppgaver som ble laget ut fra de seks skrivehandlingene. Men når det er snakk om for eksempel "de utforskende tekstene» i Normprosjektets materiale er betegnelsen «utforskende» definert ut fra skrivehandlingen som skriveoppgaven ble laget med utgangspunkt i, og ikke i trekk ved tekstene selv. På samme måte som Berge et al. (2016) synes det er problematisk å se tekster som uttrykk for «the mental state that the text was assumed to be a reflection or index of» (s. 174), er det også problematisk å se tekstene som uttrykk for skrivehandlingen som skriveoppgaven er antatt å legge opp til realiseringer av (Dagsland, 2018). Det er dermed ikke gitt at en intendert utforskende skriveoppgave genererer utforskende elevtekster, men det er heller snakk om antatt utforskende tekster (Dagsland, 2018). For utforskingsbegrepet innebærer dette at det kommer til syne en spenning mellom det å utforske som prosess og som produkt: Omtalt eller kategorisert som en "utforskende tekst», er det for eksempel ikke skriveprosessen som avgjør om teksten kan kalles utforskende eller ikke, men de språklige og lingvistiske kombinasjonene i teksten (som produkt) som gjør at man kaller den utforskende fremfor for eksempel beskrivende. Dette er en annen måte å omtale det å utforske på enn hvordan man kan omtale elevers utforsking i forbindelse med for eksempel utforskende arbeidsmåter eller ulike utforskende forsøk i naturfag, som med Skrivehjul-terminologi ofte kan tenkes å resultere i beskrivende tekster i form av rapporter eller lignende. ${ }^{6}$

\footnotetext{
${ }^{4}$ Selvsagt kan det skje noe kognitivt utforskende mens man skriver (og kanskje foregår det en form for utforsking i skrivingen av alle tekster), men dette er ikke tenkt inn i skrivehandlingen å utforske. ${ }^{5}$ En idealtype er ifølge Max Weber (1949) noe som aldri fullt og helt reflekterer virkeligheten, en metodologisk «utopia [that] cannot be found empirically anywhere in reality» i $\sin$ «rene» form (s. 90). ${ }^{6} \AA ̊$ beskrive er også en av de seks skrivehandlingene i Skrivehjulet.
} 


\section{S. Dagsland}

Et teoretisk rammeverk for forståelsen av aspekt i elevtekster

Aspekt tolkes gjerne isolert i relasjon til setningen verbalformen er en del av, men jeg vil argumentere for en kontekstuell tolkning av aspekt. Det teoretiske resonnementet for dette bygger som sagt på pragmatisk orientert aspektteori (Hopper, 1982) og dialogisk ytringsteori (Bakhtin 1995; 2005). Spesielt skal jeg koble den kontekstuelle forståelsen av aspekt til posisjoneringsanalyse (Ongstad, 1997, 2012; Smidt, 2009) og relieffanalyse (Evensen, 2005; Dagsland, 2018).

Aspekt omhandler ulike handlingers avsluttethet. Det vil si om en handling, prosess eller tilstand ses på som avsluttet, det som kalles perfektiv, eller om den er vedvarende, det som kalles imperfektiv (Hopper, 1982; Givon, 1993). Konkret innebærer aspektanalyse å undersøke hvordan verbalformen uttrykker den måten handlingen utvikler seg på, det vil si hvordan en verbalhandling fordeler seg eller ikke langs en tidsakse. Hovedgrunnen til å undersøke aspekt i elevtekster, er at prosessers avsluttethet eller vedvarenhet står i relasjon til spenningen mellom det å utforske som produkt eller prosess. Hvis man lar Skrivehjulet være premisset for hvordan man forstår det å utforske, er "utforsking» (som aktivitet eller prosess) noe som skjer $i$ en utforskende tekst, en vedvarende/pågående (imperfektiv) handling i teksten, og ikke en avsluttet handling forut for teksten (perfektiv). Hvis man skriver om en utforskende aktivitet som allerede har skjedd, der verbalformen avslører at utforskingsprosessen ses på som avsluttet (perfektiv), er kanskje teksten heller beskrivende fremfor utforskende.

Med bakhtinsk terminologi må ytringen ses i dialog med andre ytringer fremfor alene og i seg selv, og dette innebærer en kontekstuell og relasjonell forståelse av språkbruk (Bakhtin, 2005; Evensen, 2013; Dagsland, 2018). Jeg forstår Bakhtins metalingvistikk som et dobbelt perspektiv på den måten at det er en tenkemåte om språkbruk som kombinerer et blikk for den umiddelbare ytringssituasjonen med den større dialogen ytringen er en del av. Evensen (2013) oppsummerer et bakhtinsk perspektiv ved nettopp å peke på en «fused interconnectedness» (s. 156) mellom et sosialinteraksjonistisk og et sosialkonstruksjonistisk blikk, og at en bakhtinsk tilnærming til språkbruk fordrer et dynamisk perspektiv der begge er nødvendige å ta hensyn til. Dette er relevant for hvordan jeg forstår aspektbegrepet. I studier av aspekt er fokuset ofte på verbalformen på et lokalsemantisk nivå. Som formal kategori er ikke aspekt like relevant i studiet av elevytringer, men som kontekstuell kategori (jf. Hopper, 1982) kan aspekt åpne opp for å belyse eksempelvis elevenes posisjoneringer og relieffstrukturer - fenomener som følger enhver ytring. Bestemmelsen av perfektiv kontra imperfektiv i det metalingvistiske perspektivet har dermed å gjøre med den tekstlige og kontekstuelle sammenhengen verbalformen opptrer $i$, og jeg deler dermed syn med Hopper (1982): «the fundamental notion of aspect is not a local-semantic one but is discourse-pragmatic, and is characterizable as completed event in the discourse» (s. 5). Dette utgjør et funksjonelt perspektiv på aspekt der konteksten er det mest avgjørende for om noe tolkes som perfektivt eller imperfektivt. Det at norsk er et tempusprominent språk, er også et argument for en kontekstuell fortolkning av aspekt: Vi koder ikke aspekt inn i bøyningsformen slik vi gjør med tempus. Dermed 
avhenger bestemmelsen av aspekt i norsk i større grad av fortolkning enn for eksempel i fransk der aspekt er grammatikalsk.

Det å ytre seg innebærer alltid en eller annen form for posisjonering, skriver Ongstad (1997, 2012) og Smidt (2009) med utgangspunkt i Bakhtins ytringsbegrep. Posisjoneringsanalyse innebærer et blikk på hva som skjer i den umiddelbare ytringen som skapes i en spesifikk klasseromssituasjon (et sosialinteraksjonistisk perspektiv), og samtidig er posisjoneringsanalyse følsomt for hva, hvordan og hvem elevene posisjonerer seg i relasjon til eller går i dialog med i videre forstand (et sosialkonstruksjonistisk perspektiv). I det metalingvistiske perspektivet innebærer det å utforske noe å posisjonere seg i relasjon til Bakhtins tre ytringsaspekter (det ekspressive, det referensielle og det adressive): i tekstene posisjonerer elevene seg selv (《jeg》//〈selv» - uttrykk for ekspressivitet) i relasjon til hva de utforsker («det»/《verden» - uttrykk for referensialitet) og ut fra hvem de går i dialog med («du»/«samfunn» - adressivitet) i sine ytringer.

Posisjoneringsperspektivet fører i aspekt-sammenheng med seg et fokus på utsigelsessituasjonen til det tekstlige jeg-et. Det vil si hvordan jeg-et posisjonerer seg i relasjon til perfektive eller imperfektive prosesser, handlinger og hendelsesforløp. Det innebærer å undersøke om elevene posisjonerer seg som del av (vedvarende eller pågående) utforskende prosesser (imperfektiv), eller om de posisjonerer seg i relasjon til «utforskingen» som en avsluttet aktivitet (perfektiv).

Relieffteori (Evensen, 2005; Smidt \& Evensen, 1991) prøver å nærme seg fenomenet perspektiv $\mathrm{i}$ tekst, nærmere bestemt samspillet mellom en forgrunn og en bakgrunn $\mathrm{i}$ teksten. Når elevene inntar perspektiv i tekstene, er dette noe de aktivt inntar som kommunikative deltakere (Evensen, 2002, s. 388). Jeg ser altså på posisjonering og relieff som prosesser som følger enhver ytring. Kort sagt handler relieffanalyse om hvilken tekstlig funksjon ulike tekstdeler har i relasjon til hverandre, i lys av konteksten disse opptrer i. Forgrunnen er meningsfokuset som får sin mening ved å bli satt i relieff, altså i relasjon til en bakgrunn. Jeg antar at det er elementer ved dette tekstlige meningsfokuset, forgrunnen, som giør at vi oppfatter en tekst som utforskende fremfor beskrivende eller vice versa. For å ta et eksempel som er relevant for artikkelens analyser: Hvis en refererende eller beskrivende tekstdel (for eksempel et avsnitt) har en forgrunnsfunksjon i teksten som helhet, er ikke teksten utforskende, men kanskje heller en beskrivende tekst.

Relieffperspektivet i aspekt-sammenheng innebærer dermed å undersøke om forgrunnen i elevtekstene er perfektiv eller imperfektiv. Når jeg analyserer elevtekstene i lys av relieffteorien, er jeg interessert i hva som er den funksjonelt dominante aspektkategorien i teksten, og det er dette jeg er ute etter når jeg gjennom de empiriske eksemplene undersøker om tekstene har imperfektiv eller perfektiv forgrunn.

\section{Fortolkning av aspekt i elevtekster: empiriske eksempler}

I de følgende analyseeksemplene skal vi fokusere på hvordan tre elever posisjonerer seg $\mathrm{i}$ antatt utforskende tekster, og hva som er den funksjonelt dominante aspektkategorien i tekstene. Posisjonerer de seg i etterkant av en utforskning som allerede er avsluttet eller posisjonerer de seg som del av vedvarende utforskningsprosesser? 


\section{S. Dagsland}

Først skal jeg imidlertid komme inn på noe av konteksten for skrivingen, nærmere bestemt et av ressursheftene i Normprosjektet som fikk en viktig rolle for lærernes utforming av skriveoppgaver, og som kan være med på å belyse utforskingsbegrepet og de påfølgende analysene. Sammenligningen mellom og drøftingen av de empiriske eksemplene $\mathrm{i}$ en aspektsammenheng gjør jeg i den avsluttende drøftingen til slutt.

\section{Ressursheftets kjennetegn på utforskende skriving: en viktig ytring $i$ intervensjonskonteksten} Sammen med Skrivehjulet ble ulike ressurshefter brukt av klassens lærere som utgangspunkt for å lage skriveoppgaver ut fra skrivehandlingene. Ressursheftet er en tekst som henvender seg til lærerne som mottakere (fra forskergruppa i Normprosjektet), med hensikt om å konkretisere hva skrivehandlingene innebærer, og gi lærerne ressurser som de kunne bruke, slå opp i, få inspirasjon fra, og lignende. Ressursheftet er i så måte et viktig dokument for å forstå hvordan skrivehandlingene ble presentert for lærerne i mitt materiale, og en del av "utforskingssnakket» som er med på å påvirke hvordan man kan forstå utforskingsbegrepet i den konkrete historiske konteksten som intervensjonen i Normprosjektet utgjorde.

I et av disse ressursheftene ble den utforskende skrivehandlingen presentert på følgende måte:

Hva kjennetegner en utforskende skrivehandling?

- Den er det-orientert (rettet mot et fenomen der kunnskapen er usikker og må sannsynliggjøres).

- Å utforske innebærer blant annet å undersøke, drøfte, diskutere, tolke, resonnere og analysere kunnskap.

- Utforskende tekster er tekster der vi forsøker å diskutere kunnskap og stiller spørsmål for eksempel om naturen eller historiske sammenhenger (Har det vær liv på Mars eller ikke? Hvem startet 1. verdenskrig? ). Gjennom utforskende skriving kan man bl.a. oppdage sammenhenger mellom ulike fagfelt, knytte etablert kunnskap til egne erfaringer, utvide og utvikle kunnskap.

- Når man utforsker, har man ofte behov for bindeord som markerer årsak-virkning (derfor, fordi, altså, på grunn av), motsetning (men, derimot, likevel, til tross for, selv om) og betingelser (om, hvis, når, under forutsetning av).

- Eksempler på utforskende tekster: Fagartikler/fagtekster, presentasjon av prosjekter, utforskende saktekster av ulike slag.

- Formålet er primært å utvikle ny kunnskap og å utvikle ny forståelse av virkeligheten.

Jeg skal ikke gi en dyptgående analyse av disse beskrivelsene (for utdyping, se Dagsland, 2018), men peke på noen relevante spenninger som er viktige for artikkelens tematikk.

Skrivehandlingen omtales i heftene som en av tre skrivehandlinger som «er detorienterte», mens andre skrivehandlinger «er» jeg- eller du-orienterte. Bruken av «er» gjør at skrivehandlingene ble lagt fram som noe som er jeg-, det- eller du-orientert uavhengig av formål eller faglig kontekst. Å konkretisere skrivehandlingene i slike motsettende "orienteringer» fremtrer som uhensiktsmessige forenklinger, blant annet fordi det vanskeliggjør mulighetsrommet for eksempelvis jeg-rettede utforskinger 
(å utforske sin egen identitet eller egne tanker om seg selv) eller for eksempel detrettede refleksjoner (faglig refleksjon) (Dagsland, 2018).

I parentesen bak «det-orientert», spesifiseres hva som menes med dette: «rettet mot et fenomen der kunnskapen er usikker og må sannsynliggiøres» (min kursivering). Her skiller den utforskende skrivehandlingen seg fra eksempelvis den beskrivende skrivehandlingen, som også er kalt "det-orientert», men der "kunnskapen må regnes som kjent». Noe av det som skiller disse to «det-orienteringene» fra hverandre, er dermed om kunnskapen regnes som kjent (å beskrive) eller ukjent (å utforske). Spenningen mellom det å utforske som prosess og produkt kommer dermed til syne i ressursheftet på en måte som gjør en aspekttilnærming relevant. Spenningen reflekteres også flere steder, for eksempel gjennom at «presentasjon av prosjekter» blir nevnt som eksempel på utforskende tekster. Det å presentere noe minner kanskje heller om det å beskrive noe, noe man gjør når "kunnskapen er kjent». Man kan for eksempel tenke seg en beskrivende rapport fra et forsøk der oppgaven var å utforske noe: Kanskje blir teksten skrevet på en måte der "kunnskapen er kjent», mens utforskingen av det «ukjente» ligger i den avsluttede prosessen forut for skrivingen. Kan da teksten som produkt kalles utforskende, eller er den heller beskrivende?

Ressursheftet reflekterer også en spenning mellom det idealtypiske i Skrivehjulet kontra det at skrivehandlingene har konkrete empiriske "kjennetegn». Som idealtypisk motsetter Skrivehjulet som modell seg empiriske kjennetegn, mens i ressursheftet er det nettopp slike kjennetegn som listes opp. I klasseromskonteksten ble beskrivelsene formidlet nærmest som sjangerkjennetegn for «hvordan-vi-gjør-det» når elevene skulle skrive utforskende tekst (Dagsland, 2018).

\section{Den første skriveoppgaven: universelle innsikter, evalueringer og gjentatte handlinger}

Hopper skriver at det klassiske eksempelet på perfektiv utgjøres av kronologisk ordnede hendelser der hver ny hendelse avslutter den forrige. Om det imperfektive derimot, skriver han følgende:

By contrast, states, on-going processes, and repeated events are not limited in this way, and do not need to be perceived discretely since overlapping does not obscure the chronological order of events, it being characteristic of states and on-going actions not to be so ordered. (Hopper, 1982, s. 6)

Tilstander, pågående prosesser og gjentatte hendelser er dermed ifølge Hopper eksempler på imperfektiv. Hvis en handling, hendelse eller prosess $i k k e$ kan sies å ha eller få en avslutning i teksten, tolker jeg dette som imperfektiv (vedvarende).

Den første elevteksten jeg skal bruke som eksempel, er skrevet av eleven Morten $(\mathrm{m} 615)^{7}$, og er svar på følgende skriveoppgave: «Skriv en utforskende tekst der du sammenligner det å regne med positive tall og det å regne med negative tall». Elevene

${ }^{7}$ Mye av materialet fra Normprosjektet ("Normkorpuset") ligger digitalt tilgjengelig på Tekstlabbens hjemmesider: https://tekstlab.uio.no/glossa2/norm Der er m615 elevkoden til "Morten". 


\section{S. Dagsland}

blir i oppgaveformuleringen bedt om å skrive en utforskende tekst, og om å sammenligne. «Sammenligne» var listet opp som et synonym til det å utforske i den versjonen av Skrivehjulet som ble brukt av lærerne (her står det: «å utforske, drøfte, diskutere, sammenligne, analysere, tolke, resonnere»). Slik knytter skriveoppgaven seg til hvordan skrivehandlingen ble presentert i Normprosjekt-konteksten. Det er sammenligning læreren Knut legger vekt på når skriveoppgaven introduseres for elevene i klasseromskonteksten. Det elevene skal sammenligne, er «det å regne med positive tall» og «det å regne med negative tall». Altså fokuserer skriveoppgaven på hvordan man går frem når man regner med det ene og det andre, det vil si det operasjonelle (kontra det begrepsmessige) ved positive tall og negative tall. Skriveoppgaven er åpen med hensyn til hvilke forskjeller eller likheter man vil skrive om, og om man vil konsentrere seg om én eller flere regnearter. Åpenheten understrekes også av lærer Knut i klasseromskonteksten.

Skriveoppgaven gis som del av en periode der negative tall er på klassens arbeidsplan, og det er dette som er "det nye» temaet for klassen i denne perioden. I klasseromssituasjonen sier Knut at «du må sikkert regne noen mattestykker for å oppdage ting. Og så skriver du en tekst om det etterpå». Det kan diskuteres om det er i selve utprøvingen (《regne noen mattestykker for å oppdage ting») av regnestykkene det utforskende ligger, eller om det er i skrivingen av teksten ("og så skriver du en tekst om det [utforskingen?] etterpå). Slik reflekteres spenningen mellom det å utforske som prosess og produkt $\mathrm{i}$ både oppgaveformuleringen og i lærerens introduksjon av skriveoppgaven.

Morten har skrevet følgende tekst på arket sitt (se transkripsjon i vedlegg 2):

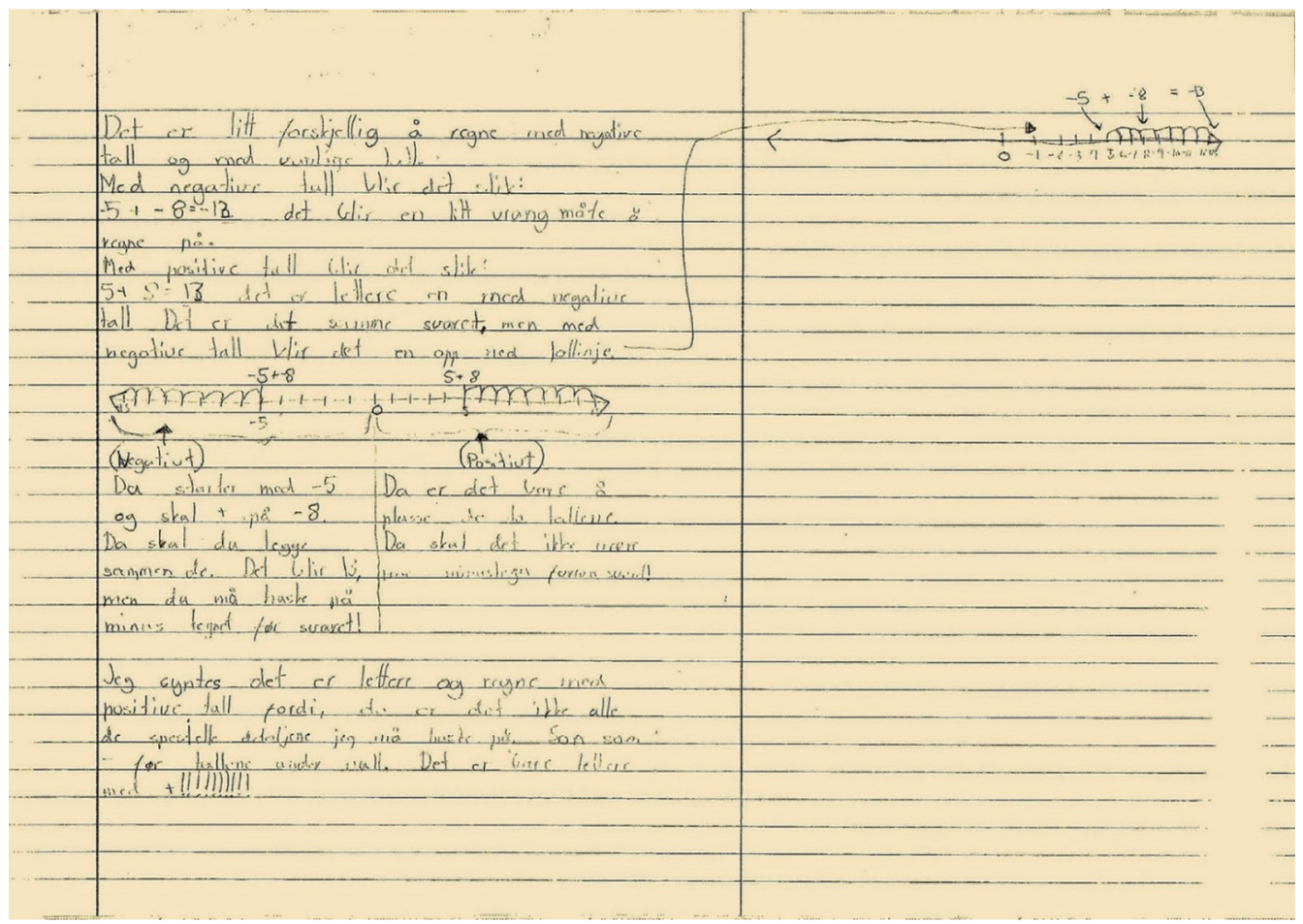


Mortens tekst er et eksempel på en tekst som med relieffteoretisk terminologi har en imperfektiv forgrunn. Uten overskrift begynner han teksten sin med å slå fast at: «Det er litt forskjellig å regne med negative tall og med vanlige tall» (min kursivering). Meningen som formidles, er generalisert, universell og vedvarende. Han posisjonerer seg på en fastslående måte i denne første setningen, selv om ordet «litt» fungerer som en demper. Den globale forgrunnen i teksten utgiøres av deler der Morten beskriver, forklarer og redegjør for hva det å regne med positive og negative tall er og blir. Han slår fast hvordan det «er» og viser leseren hvordan det «blir», uten eksempelvis å skrive «jeg tror»: «Med negative tall blir det slik: $-5+-8=-13$ det blir en litt vrang måte å regne på. Med positive tall blir det slik:», «Det er lettere», osv. Eksemplene på hvordan det «blir» får en imperfektiv funksjon fordi eksemplene innebærer gjentatte hendelser (iterativ). Det «blir slik» ikke bare i de spesifikke regnestykkene han bruker som eksempler, men også når man regner med positive og negative tall generelt. Morten skriver ikke om «hva jeg gjorde den gang da jeg regnet ut», men hvordan man generelt giør i regnestykker som dette. Imperfektive tilstander i Mortens tekst finner vi eksempler på når det påkalles statiske og universelle regler og innsikter, eller for eksempel når det generaliseres. Det vil si at konstruksjoner som er uttrykk for noe generisk, inkluderes i det jeg tolker som imperfektiv: "an event fails to be perfective if it is stative" (Timberlake, 1982, s. 317).

Evalueringene mot slutten av teksten er også eksempel på imperfektiv, fordi jeg tolker dette som tilstander: "Jeg syntes det er lettere og regne med positive tall fordi, da er det ikke alle de spesielle detaljene jeg må huske på. Son som - før tallene under null. Det er bare lettere med +!!!!!!!». Evalueringen er også et eksempel på at elevene ofte kan være inkonsistente med for eksempel verbalformen (syntes og ikke synes). I lys av konteksten (spesielt giennom bruken av «er») tolker jeg det som at Morten mener «synes» her.

Som Morgan (1998) påpeker, er lærebøkene en sentral del av tekstkulturen i matematikkfaget, og elevene i min studie (Morten inkludert) imiterer lærebokens posisjonering i tekstene de skriver. De beskriver, forklarer, definerer, viser og instruerer, og flere har evaluerende bakgrunnsavsnitt mot slutten av teksten, som ligner Mortens. Morten bruker eksempelvis flere piler til å vise og forklare leseren. Denne forklarende eller beskrivende posisjoneringen i forgrunnen, understrekes av at han synes å forestille seg en mottaker som vet "mindre enn ham selv», og kan minne om en lærebokleser: «jeg skal jo egentlig forklare det til. til noen som ikke vet hva positive og negative tall er» (Morten, intervju). Dermed posisjonerer han seg i relasjon til ytringens «det» på en måte der han fremstår som en som vet hva det å regne med positive og negative tall innebærer. Det gjør han både over og under tallinjen på midten av arket.

De imperfektive innsiktene og tilstandene Morten trekker fram i forgrunnen av teksten sin, tolker jeg ikke som uttrykk for en pågående utforsking, men det slås fast at «slik er det». Dette gjør at han ikke posisjonerer seg som del av en utforskingsprosess som foregår underveis i teksten, men han behandler kunnskapen han skriver om som kjent, vedvarende og universell. Aspektanalyse legger dermed opp til en diskusjon om tekster som dette kan kalles utforskende. Som jeg vil komme inn på i den avsluttende drøftingen, går det an å diskutere om teksten kanskje heller bør kalles beskrivende. 
Den andre skriveoppgaven: Utforsking som noe tilbakelagt eller som noe pågående I min fortolkning av perfektiv i elevtekstene, tar jeg spesielt utgangspunkt i at Hopper (1982) understreker at hendelsen eller prosessen det er snakk om skal ha en avslutning i konteksten den er en del av. Han skriver bl.a. at "closure is the most important feature for triggering the perfective» (s. 15), noe som støttes av både Timberlake (1982) og Faarlund, Lie og Vannebo (1997). Hopper trekker fram at typiske eksempler på perfektiv er kronologisk ordnede hendelsesforløp der de ulike hendelsene i forløpet bygger videre på (og dermed lukker) hverandre, eller hendelser som har skjedd én gang og ikke kommer til å skje igjen. Det vil si at det perfektive ses på som avsluttethet med hensyn til det neste som skjer eller har skjedd.

Skriveoppgaven som de to neste eksemplene er svar på, er formulert som følger:

Nå har dere utført en rekke kast og ført opp resultatene i en tabell. Dere har snakket om ulike hypoteser som går an å "spørre» om og finne ut av. Velg en av hypotesene, eller lag en helt ny en som du har lyst til å undersøke nærmere. Skriv en tekst der du utforsker den hypotesen du har valgt. Tenk deg at teksten skal leses av andre i klassen som har valgt andre hypoteser enn din egen. Bruk både tegning og skriving for å vise leseren hvordan du utforsker og finner ut av hypotesen din.

Dette er en skriveoppgave basert på et opplegg («svampkasting») hentet fra Geir Bottens bok Meningsfylt matematikk (Botten, 2003, s. 125-127). En omgjøring av Bottens forslag ble utarbeidet og planlagt av lærerne, ut fra hva de syntes det var relevant å jobbe med. Selve skriveoppgaven kom mot slutten av dette lengre undervisningsopplegget, der elevene gruppevis hadde kastet risposer (tre kast med hver hånd) på blinker tegnet på asfalten i skolegården, før de samlet klassens resultater i et felles Excel-ark.

Den samme spenningen som jeg har vært inne på tidligere finnes både i skriveoppgaven og i introduksjonen av den: Skriveoppdraget er tydelig på at det er i teksten man skal utforske («skriv en tekst der $d u$ utforsken», «å vise hvordan du utforsken» og ikke utforsket). Samtidig krever skrivesituasjonen at man nærmest må utforske hypotesen sin før man skriver om den, og at noe av utforskingen som prosess kanskje skjer i Excel-arket heller enn i teksten som skal skrives. Dermed kommer spenningen mellom en utforskende aktivitet (som prosess) og en utforskende tekst (som produkt) til syne i både skriveoppgaven og i klasseromssituasjonen.

Skriveoppgaven er åpen med hensyn til om hypotesen man velger stemmer eller ikke. Valg av hypotese er også noe som avgjør hvor sikker man kan være. Måten læreren introduserte denne skriveoppgaven på i klasserommet, understreker nettopp denne åpenheten: Lærer Knut er ikke opptatt av at elevene må velge hypoteser som nødvendigvis er valide og sikre (og som elevene tror stemmer på forhånd). Slik sett er fokuset annerledes i denne skriveoppgaven enn i skriveoppgaven som handler om å skrive om positive og negative tall: Det finnes ikke nødvendigvis ett gitt forhåndsbestemt svar som kan finnes i læreboken. Dette til forskjell fra hva som kan sies å være tilfellet i den første skriveoppgaven.

Den følgende elevteksten er et eksempel på en tekst som har en perfektiv forgrunn, og er skrevet av Mia (m610). Som med Mortens tekst, legger aspekttilnærmingen 
opp til en diskusjon av om tekster som dette kan være utforskende. Ut fra skriveoppgavekonteksten er det flere av prosessene som allerede er avsluttet før skrivingen: kastene som er gjort, klassens innføring av resultater i Excel-skjema og gruppearbeid med muntlig diskusjon av hypoteser. Mia skriver:

\section{KASTELEKEN}

Kasteleken gikk ut på at vi kastet en rispose på en blink som var tegnet på bakken. Når vi skulle kaste sto vi bak en strek som var ca. 3 meter unna blinken. Hypotesen min er at jentene kaster bedre med venstre hånd enn guttene fordi mange jenter holder på med fotball og når det er innkast må man kaste, og da blir man god til å kaste. I denne teksten skal jeg fortelle
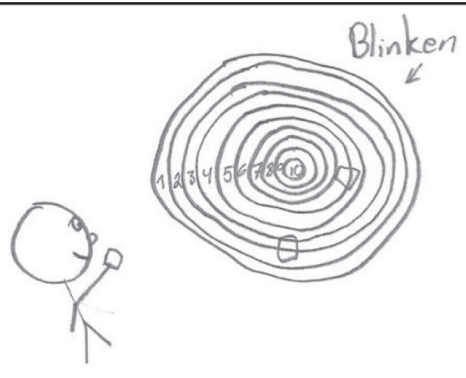
om hypotesen min og om den var riktig eller feil.

For å finne ut om hypotesen min var riktig eller ikke måtte jeg først finne ut hvor mange poenger på venstre hånd vær elev hadde. Jeg la sammen poengene på venstre hånd til vær elev også fant jeg ut totalsummen til alle elevene.

Her er gjennomsnittet til jenter og gutter:

Jenter: 13,42857142

Gutter: 16,1875

Etter jeg fant ut gjennomsnittet til jentene og guttene så jeg at hypotesen min ikke var riktig fordi det var guttene som hadde fått flest poeng.

Eleven begynner teksten sin med overskriften «Kasteleken» og skriver videre: «Kasteleken gikk ut på at vi kastet en rispose på en blink som var tegnet på bakken». Dette er eksempel på perfektiv, dvs. avsluttede handlinger som henviser til et spesifikt fortidig hendelsesforløp der kastene er avsluttede aktiviteter. Med relieffanalytisk blikk er de første setningene bakgrunnselementer som har en kommunikativ funksjon overfor leseren. Videre skriver hun: «Hypotesen min er at jentene kaster bedre med venstre hånd enn guttene fordi mange jenter holder på med fotball og når det er innkast må man kaste, og da blir man god til å kaste». Dette er eksempler på imperfektiv. «Hypotesen min er at jentene kaster bedre med venstre hånd enn guttene» tolkes som imperfektiv, på grunn av «er». Begrunnelsen, «fordi mange jenter holder på med fotball», er heller ikke noe avsluttet, men en vedvarende tilstand. Mia skriver at «når det er innkast må man kaste, og da blir man god til å kaste». Dette tolkes også som imperfektiv fordi det ikke er bundet til et spesifikt hendelsesforløp som har skjedd, men gjelder gjentatte hendelser uavhengig av tid.

I innledningen skriver Mia at: «I denne teksten skal jeg fortelle om hypotesen min og om den var riktig eller feil». Med relieffanalytisk blikk har dette en såkalt metafunksjon (Hundal, 2017, s. 88) og fungerer også som kommunikativ bakgrunn for leseren. Mias setning sier noe om fremtid, for i lesesituasjonen er hypotesens 


\section{S. Dagsland}

«riktige» eller «feilaktige» svar i fremtiden selv om det kanskje i skrivesituasjonen ligger i fortiden for skriveren. "[S] kal jeg fortelle om» er en vedvarende aktivitet, men utforskingen hun posisjonerer seg i relasjon til, er avsluttet. Hendelsesforløpet Mia posisjonerer seg som del av, stemmer overens med det nevnte eksempelet Hopper (1982) trekker frem som et typisk eksempel på perfektiv: kronologisk ordnede hendelsesforløp der de ulike hendelsene i forløpet bygger videre på (og dermed lukker) hverandre, eller hendelser som har skjedd én gang og ikke kommer til å skje igjen: «For å finne ut om hypotesen min var riktig eller ikke måtte jeg først finne ut hvor mange» og deretter «la sammen poengene» og deretter «fant jeg ut totalsummen til alle elevene». Tekstens utsigelsessituasjon, «her og nå», er en posisjonering der hun som elev redegjør for hva hun gjorde den gang da, og der hun «fant ut» at "hypotesen min ikke var riktig». Konklusjonen er også perfektiv: «Etter jeg fant ut gjennomsnittet til jentene og guttene så jeg at hypotesen min ikke var riktig fordi det var guttene som hadde fått flest poeng». Teksten er dermed et eksempel på en tekst med perfektiv forgrunn, og utforskingen hun posisjonerer seg i relasjon til er gjennomgående avsluttet.

Selv om "Her er gjennomsnittet» isolert sett kan tolkes som imperfektiv (på grunn av «er»), er det i relasjon til konteksten et eksempel på det Hopper (1982) kaller «resultative perfect» (s. 11). Kort sagt dreier «resultative perfect» seg om at resultatet av et perfektivt hendelsesforløp tolkes som perfektivt selv om dette resultatet isolert sett kan karakteriseres som en «ny vedvarende/statisk tilstand». For å avgjøre om slike tilfeller er perfektive eller imperfektive, må man vurdere hvilken kontekst det står som del av:

States and conditions resulting from a previous action form a well established verbal category in many languages. According to whether the on-going state or the antecedent action is viewed as fundamental, the resultant perfect may be semantically allied with a continuing state or a completed action. (Hopper, 1982, s. 12)

Når det foregående hendelsesforløpet blir sett på som styrende, blir den nye tilstanden tolket som perfektiv. Konteksten for setningen er som sagt et perfektivt hendelsesforløp som er kronologisk ordnet, og videre i elevteksten skriver hun: «Etter at jeg fant ut gjennomsnittet (...) så jeg at hypotesen min ikke var riktig». I Mias tekst er dermed gjennomsnittet resultatet av «hvordan jeg gjorde». Hopper skriver: "The resultative perfect then is a semantic extension of the basic function of the perfective aspect, to indicate events that are in sequence and are therefore bound by one another» (s. 13). I dette tilfellet er det dermed den perfektive konteksten som blir utslagsgivende for fortolkning av «Her er gjennomsnittet» som «resultative perfect» og ikke som imperfektiv. Det vil si at "the antecedent action is viewed as fundamental» og da ses "her er gjennomsnittet» som uttrykk for en avsluttet handling og ikke en vedvarende tilstand (jf., Hopper 1982, s. 12). Dette vil jeg påstå er typisk for tekster der spesifikke hendelsesforløp i teksten resulterer i en ny tilstand eller en ny innsikt, når elever for eksempel skriver om noe de har lært eller tilegnet seg, og der $\mathrm{de}(\mathrm{n})$ «nye innsikten(e)» er bundet til et spesifikt perfektivt hendelsesforløp. 
Dette er også et eksempel på at tempus i seg selv ikke er bestemmende for perfektiv kontra imperfektiv, og at norsk ikke er et aspektprominent språk. Presens og preteritum øker eller reduserer mulighetene for en imperfektiv eller perfektiv fortolkning, men er ikke avgjørende. Det hadde for eksempel vært vanskeligere å tolke preteritumsformen $\mathrm{i}$ 《[g]jennomsnittet var» som imperfektiv, men på grunn av presensformen øker muligheten for imperfektiv tolkning.

\section{Utforskingsprosessen som noe pågående - et sammenlignende eksempel}

Petters (m613) tekst (svar på samme skriveoppgave) er et eksempel som på den ene siden har en del likhetstrekk med det forrige når det gjelder relieff, og på den andre siden skiller seg fra det forrige når det gjelder posisjonering med hensyn til aspekt.

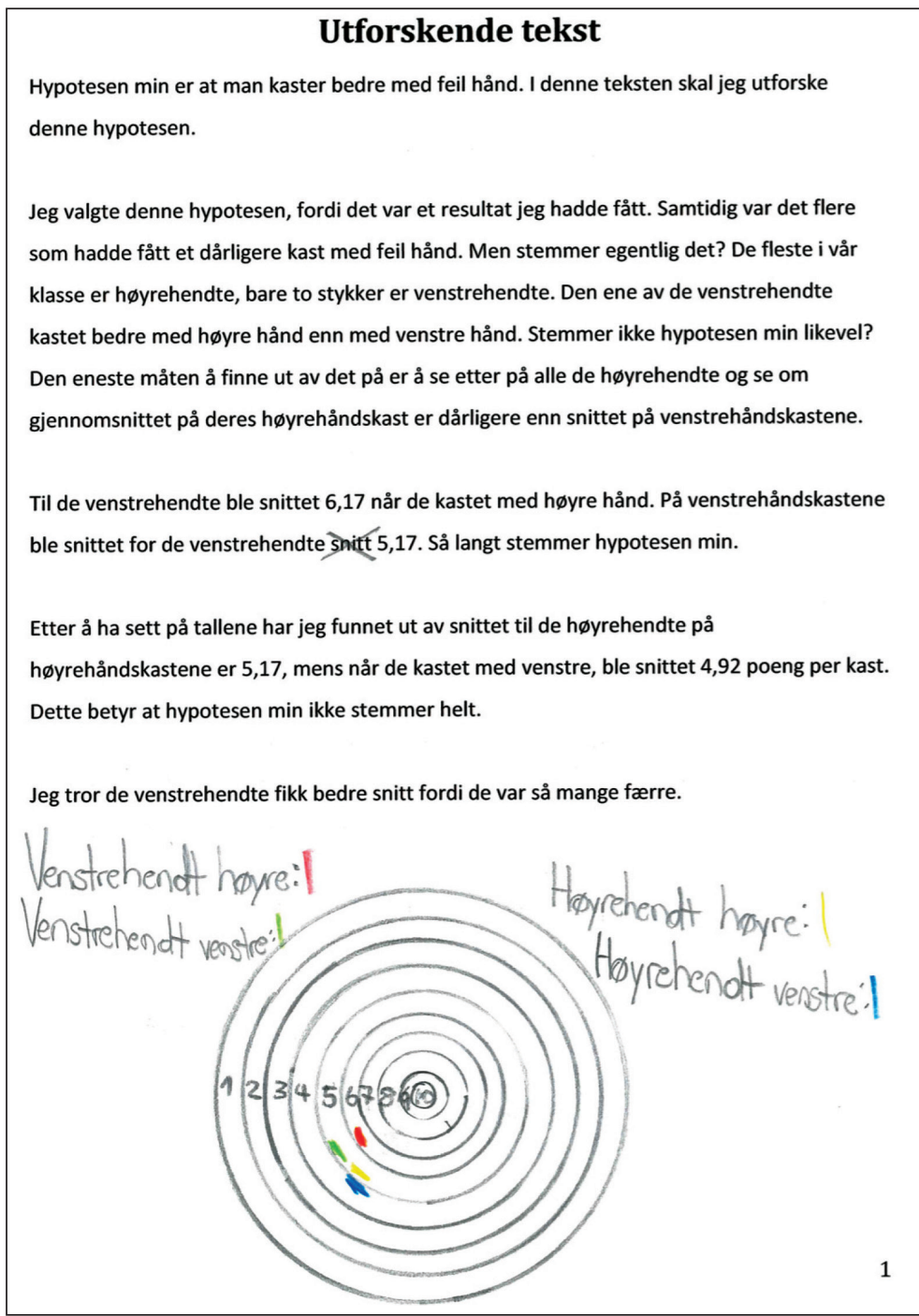




\section{S. Dagsland}

Tekstens innledning (de to første setningene) er imperfektiv fordi det er snakk om vedvarende og pågående handlinger og prosesser, og den leses som kommunikativ bakgrunn. Petter posisjonerer seg videre på en måte der kastingen og valget av hypotese er tilbakelagte og avsluttede hendelser ("Jeg valgte denne hypotesen, fordi det var et resultat jeg hadde fått»).

Utforskingen av hypotesen presenterer eleven derimot som en pågående prosess. Måten Petter gjør dette på, er blant annet gjennom å stille spørsmålene «Men stemmer egentlig det?» og «Stemmer ikke hypotesen min likevel?». Disse spørsmålene er ikke perfektive, for han skriver som om han ennå ikke vet om hypotesen stemmer eller ikke. Dette skiller seg fra Mias tekst, der utforskingsprosessen er avsluttet gjennom hele teksten, og der hun skal «fortelle om (...) den var riktig eller feil». Petters setning «Den eneste måten å finne ut av det på er å se etter på alle de høyrehendte og se om gjennomsnittet på deres høyrehåndskast er dårligere enn snittet på venstrehåndskastene» handler ikke eksplisitt om hvordan «jeg gjorde», men sier noe om hva et generalisert hvem-som-helst må gjøre for «å finne ut av det på». Etterpå følger «Til de venstrehendte ble snittet 6,17 når de kastet med høyre hånd. På venstrehåndskastene ble snittet for de venstrehendte 5,17.» Dette tolkes som "resultative perfect» fordi det er et resultat av foregående handlinger («når de kastet med høyre hånd»). «Så langt stemmer hypotesen min", skriver Petter videre, og igjen tolkes dette som "resultative perfect».

Han skriver: «Etter å ha sett på tallene har jeg funnet ut av snittet til de høyrehendte på høyrehåndskastene er 5,17, mens når de kastet med venstre, ble snittet 4,92 poeng per kast. Dette betyr at hypotesen min ikke stemmer helt.» Her avsluttes prosessen «å finne ut», og innsikten «Dette betyr at hypotesen min ikke stemmer helt» er resultatet av den tidligere pågående utforskende prosessen (resultative perfect). Siden de åpne mulighetene får en avslutning i tekstens konklusjon, er også Petters tekst en tekst der forgrunnen er perfektiv (i likhet med Mias tekst). Likevel posisjonerer Petter seg annerledes med hensyn til aspekt enn Mia. I Mias tekst er utforskingen noe som omtales som allerede avsluttet og tilbakelagt gjennom hele teksten, mens Petter derimot posisjonerer seg i relasjon til utforskingen som noe pågående ( Men stemmer egentlig det?», «Stemmer ikke hypotesen min likevel?») selv om disse åpne mulighetene får en avslutning mot slutten («Dette betyr at hypotesen min ikke stemmer helt»).

\section{Oppsummering og drøfting: Utfordringer ved det «antatt utforskende»}

I denne avsluttende drøftingen skal jeg, med utgangspunkt i de tre eksempeltekstene, oppsummere og drøfte hvordan tilnærmingen til aspekt bidrar med en problematisering og konkretisering av utforskingsbegrepet i Skrivehjulet. Poengene fremhevet i artikkelen gjelder ikke for alle utforskende tekster eller skriveoppgaver, og hensikten er ikke å generalisere eller finne ut av hva det å utforske fast og endelig «er» i matematikk eller generelt. Likevel kan aspekt-tilnærmingen gi en indikasjon på utfordringer ved det antatt utforskende, både når det gjelder Skrivehjulets skrivehandling, (intendert) «utforskende» oppgaveformuleringer og (antatt) utforskende elevtekster. 
Det første eksempelet (Mortens tekst om positive og negative tall) er et eksempel på en imperfektiv tekst fordi tekstens forgrunn består av vedvarende aspektegenskaper gjennom påkallelse av regler, universelle innsikter og kunnskaper. Det er verdt å merke seg at i tekster som er imperfektive på denne måten, kan ikke utforskingen sies å være en pågående prosess, for han trekker nesten utelukkende inn statiske og universelle innsikter som gjelder uansett tilfelle. Det går an å diskutere om slike tekster primært er utforskende, eller om de heller er beskrivende. Det er også verbene beskrive og forklare som Morten bruker om sin egen tekst i intervjuet. Han vil beskrive eller forklare hvordan man regner på de forskjellige måtene, for å gjøre det forståelig for leseren: «Det er egentlig for at jeg skal beskrive til en annen person da. Hvordan jeg skal gjøre det» (Morten i intervju). Mortens imperfektive innsikter om hvordan det «er» (og alltid har vært eller alltid blir) passer for eksempel godt sammen med hvordan Normprosjektet presenterer kjennetegnene på det å beskrive i ressursheftet ("der kunnskapen er kjent»), og står i en viss spenning med beskrivelsene av den utforskende skrivehandlingen.

Aspekttilnærmingen viser hvordan spenningen mellom å utforske som prosess og produkt kommer til syne i Skrivehjulet, i ressursmateriellet som konkretiserte modellen i Normprosjektsammenheng, i skriveoppgavene og i elevtekstene. Morten beskriver, forklarer og evaluerer, men utforsker han? Vi snakker om dette i intervjuet: «Nei, jeg synes egentlig ikke jeg har med så veldig masse utforskende ting her. Det mest utforskende er jo... ehm, jeg måtte utforske litt kanskje for å finne ut svaret og sånn, utforske litt hvordan jeg skulle beskrive, hvordan jeg skulle beskrive hvordan man gjorde det» (Morten, intervju). Skjer det utforskende i skriveprosessen før skrivingen, slik Morten er inne på, eller må utforskingen foregå i teksten (som produkt) for at teksten skal kunne kalles utforskende? Lignende spørsmål kan stilles om Mias tekst (eksempel to), der analysene viser at hun posisjonerer seg i etterkant av en allerede avsluttet utforskende prosess. Er teksten utforskende når utforskingen oppgaven spør etter, fant sted i fortiden, og man nå forteller og beskriver «hva man fant ut av» (den gang da)?

Aspektanalysene viser at Mia, når hun skriver om hypotesen sin, posisjonerer seg som en elevskriver som forteller om eller redegjør for fremgangsmåten i en allerede avsluttet prosess. Posisjoneringen til Mia kjennetegnes av at «jeg» ikke utforsker noe, men har utforsket noe. Kan en slik tekst være utforskende hvis det er i teksten utforskingen skal skje? Nei, ikke hvis vi tar utgangspunkt i Skrivehjulets beskrivelser av skrivehandlingen. Elevteksten er ett av mange eksempler på en antatt utforskende tekst der utforskingen verken er pågående eller vedvarende i teksten, men gjennomgående avsluttet. Igjen ser vi hvordan skrivehandlingen å utforske står i spenning til det å beskrive noe.

I Charles Bazermans bok The languages of Edison's light (1999), tar forfatteren for seg hvordan Thomas Alva Edison og hans utforskende kumpaner skrev tekster som del av sin innovative (ut)forsking: «these are action-oriented plans about what should be done, informally setting out tasks to be done as well as results. (...) record formal and explicit descriptions» (s. 59-60) og «showing the interaction of the train of ideas, problems, experiments, and results that had led one down a path of investigation and discovery so that others might follow the path of reasoning and continue 


\section{S. Dagsland}

with their own investigations» (s. 57). Dette er interessant fordi beskrivende tekster dermed viser seg som en viktig del av utforskingen som prosess for Edison og hans forskningsfeller, noe som også er viktig i all forskning. Det vil si at det å beskrive, fortelle om, forklare osv. har en sentral tilknytning til det å utforske noe, og dette er interessant for spenningen mellom det å utforske som prosess og produkt. Dermed er det kanskje også naturlig at når skriveoppgaver spør om utforsking, så ligger det å beskrive nært utforsking som prosess. Det er ikke tvil om at elevene har utforsket og funnet ut av noe, men teksten som tekst er ikke nødvendigvis utforskende hvis merkelappen "utforskende» krever at det er i teksten det utforskende skal skje. Likevel er det slik at Morten og Mia beskriver på litt ulike måter. Mortens imperfektive (og "generiske») tekst er beskrivende på en annen måte enn Mias, der sistnevnte tekst har et perfektivt hendelsesforløp i forgrunnen. I begge tilfeller kan det stilles spørsmål ved om utforskingen er noe som skjer i tekstene, eller om tekstene (som produkter) kanskje heller burde kalles beskrivende. Mortens tekst har imperfektiv forgrunn, mens Mias og Petters tekster har begge perfektiv forgrunn. Det vil si at det ikke er skillet mellom perfektiv og imperfektiv $i$ seg selv som er avgiørende for et eventuelt skille mellom det utforskende og det beskrivende, men en kontekstuell tilnærming til aspekt kan være med på å belyse dette fra tilfelle til tilfelle.

Hva er det som eventuelt giør Petters tekst (eksempel tre) «mer utforskende»? Basert på aspektanalysene ser vi at Petters spørsmål i teksten («stemmer ikke hypotesen min likevel?») fungerer som et språklig virkemiddel som gir uttrykk for at utforskingen skjer "nå» i teksten. I Petters tekst er aspektuelle bytter mellom perfektiv og imperfektiv, og skifte i tempus, brukt som virkemidler for å opprettholde utforskingen som pågående, selv om han trolig vet svaret på disse spørsmålene allerede i skrivesituasjonen. I hvert fall bruker Petter noen språklige virkemidler som har en funksjon som om utforskingen foregår i teksten. I intervjuet sier han at han ikke brukte de nevnte spørsmålene bevisst, men at det å skrive spørsmål inn i teksten var noe som «kom naturlig». "Da blir det mer utforskende», sier han uten å utdype hva som giør slike spørsmål utforskende når jeg spør ham om dette. Her er vi igjen i kjernen av diskusjonen om det antatt utforskende: Er teksten til Petter et eksempel på en tekst som er «mer utforskende» enn Morten og Mias tekst, fordi han posisjonerer seg i relasjon til utforskingen som en pågående aktivitet i elevteksten, til forskjell fra å posisjonere seg utelukkende i etterkant av en allerede avsluttet aktivitet eller å henvise til universelle og statiske tilstander? En aspekttilnærming til elevtekster åpner opp en slik diskusjon, og kan bidra med å konkretisere hva man kan se etter i antatt utforskende elevtekster. Tekster der elevene posisjonerer seg som del av pågående utforskingsprosesser, er kanskje mer utforskende enn de tekstene hvor de posisjonerer seg i etterkant av en avsluttet prosess eller henviser til universelle og statiske innsikter. I hvert fall gjelder dette når utforsking er definert som noe som skal skje i teksten.

Aspektkategorien kan være relevant for skriveforskere så vel som for lærere. For skriveforskere viser aspekt seg som en relevant kategori for å studere begrepet (antatt) utforsking i elevtekster. Artikkelens bidrag er en videreutvikling av aspekt 
som relevant fenomen å se etter i en slik sammenheng. Som formal kategori virker ikke aspekt like relevant, men som kontekstuell kategori (basert på Hopper, 1982) kan aspekt åpne opp for å belyse elevers posisjoneringer og relieffstrukturer - fenomener som følger enhver ytring.

For lærere er en aspekttilnærming nok mest relevant i en oppgavelagings- eller vurderingssituasjon. Flesteparten av utforskingsoppgavene formulert av lærerne i Normprosjektet ber for eksempel elevene om å beskrive eller fortelle om en utforskende aktivitet, der man på en eller annen måte skal skrive om hvordan man utforsket den gang da man utforsket (Dagsland, 2018). Dette representerer en utfordring for læreren som skal lage intendert utforskende skriveoppgaver ut fra Skrivehjulet og/eller undervise $\mathrm{i}$ "utforskende skriving». Aspektkategorien kan være med på å svare på denne utfordringen. Spørsmål som Petter har med i hypoteseteksten sin, er eksempler på virkemidler med en aspektuell dimensjon som kan være relevant å snakke med elever om. Aspektkategorien kan være relevant hvis man i klasserommet skal samtale om hvordan det «å utforske noe» for eksempel skiller seg fra det å referere til eller beskrive en fremgangsmåte. Skillet mellom det perfektive og imperfektive kan være utgangspunkt for samtaler med elever om deres egne tekster, selv om disse ordene i seg selv nok ikke bør brukes overfor elever. For eksempel kan man snakke om hvordan man kan få leseren «med på utforskingen» i teksten sin gjennom å skrive «som om» den foregår her og nå og ennå ikke er noe avsluttet. Ikke minst kan det være relevant å snakke med elever om hvilken funksjon slike spørsmål har i teksten, og hva det giør med hvordan leserne oppfatter teksten. I en funksjonelt orientert skriveopplæring kan aspekt på denne måten være med på å konkretisere dimensjoner ved den utforskende skrivehandlingen overfor elever og lærere, og et utgangspunkt for å snakke om hvordan vi fremstår og posisjonerer oss i tekst.

\section{Forfatteromtale}

Sindre Dagsland er førsteamanuensis i norskdidaktikk ved NTNU, Institutt for lærerutdanning. Han skriver om og forsker på elevers skriving av tekster i ulike fag, og elevers og lærerstudenters skaping av estetiske uttrykk i norskfaget.

\section{Takk}

Takk til de anonyme fagfellene for konstruktive innspill, og ikke minst takk til professor Mari-Ann Igland ved Institutt for lærerutdanning (NTNU) for gjennomlesning og gode råd.

\section{Litteratur}

Bakhtin, M. (1995). Teksten som problem i lingvistikk, filologi og andre humanistiske videnskaber. (N. M. Andersen \& S. Klimenko, Overs.). I L. B. Jensen (Red.), Kultur og klasse 79 (s. 43-69). København: Forlaget Medusa. 


\section{S. Dagsland}

Bakhtin, M. (2005). Spørsmålet om talegenrane (R. Slaatelid, Overs.). Oslo: Pensumtjeneste.

Bal, M. (2002). Travelling concepts in the humanities: A rough guide. Toronto: University of Toronto Press.

Bazerman, C. (1999). The languages of Edison's light. Cambridge: The MIT Press.

Berge, K. L. (2006). Skolens tekstfag og tverrfaglig skriveopplæring: En presentasjon og diskusjon av viktige trekk ved en norsk skolereform basert på literacy-tenkning. Svenskans beskrivning, 28, s. 19-40.

Berge, K. L., Evensen, L. S., \& Thygesen, R. (2016). The Wheel of Writing: A model of the writing domain for the teaching and assessing of writing as a key competency. The Curriculum fournal, 72(2), s. 172-189.

Berge, K. L., Skar, G. B., Matre, S., Solheim, R., Evensen, L. S., \& Thygesen, R. (2017). Introducing teachers to new semiotic tools for writing instruction and writing assessment: consequences for students' writing proficiency. Assessment in Education: Principles, Policy \& Practice, 24(3).

Bjørshol, S., \& Nolet, R. (Red.). (2017). Utforsking $i$ alle fag. Oslo: Cappelen Damm Akademisk.

Botten, G. (2003). Meningsfylt matematikk: Nerhet og engasjement i lceringen. Straume: Caspar forlag.

Dagsland, S. (2015). Om relasjonen skrivehandling-skriveoppgave-elevtekst: utfordringer ved antatt reflekterende elevtekster. I H. Otnes (Red.), Å invitere elever til skriving: ulike perspektiver på skriveoppgaver (s. 201-220). Bergen: Fagbokforlaget.

Dagsland, S. (2018). Om å jakte på heffalomper: Et metalingvistisk perspektiv på antatt reflekterende og antatt utforskende skriving i norsk og matematikk (Doktoravhandling). Norges teknisk-naturvitenskapelige universitet, Trondheim.

Dysthe, O., Hoel, T. L., \& Hertzberg, F. (2010). Skrive for å lare: skriving i høyere utdanning. Oslo: Abstrakt.

Evensen, L. S. (2002). Convention from below: Negotiating interaction and culture in argumentative writing. Written Communication, (19), s. 382-413.

Evensen, L. S. (2005). Perspektiv på innhold? Relieff i ungdomsskoleelevers eksamensskriving. I K. L. Berge, L. S. Evensen, F. Hertzberg, \& W. Vagle (Red.) Ungdommers skrivekompetanse: Norskeksamen som tekst (bd. 2, s. 191-236). Oslo: Universitetsforlaget.

Evensen, L. S. (2010). En gyldig vurdering av elevers skrivekompetanse? I J. Smidt, I. Folkvord, \& A. J. Aasen (Red.), Rammer for skriving (s. 13-33). Trondheim: Tapir akademisk forlag.

Evensen, L. S. (2013). Applied linguistics: Towards a new integration? Sheffield: Equinox.

Faarlund, J. T., Lie, S., \& Vannebo, K. I. (1997). Norsk referansegrammatikk. Oslo: Universitetsforlaget.

Givón, T. (1993). English grammar: A function-based introduction. Amsterdam: John Benjamins Publishing Company.

Gorman, T. P., Purves, A. C., \& Degenhart, R. E. (Red.). (1988). The IEA study of written composition 1: The international writing tasks and scoring scales. Exeter: Pergamon Press.

Hertzberg, F. (2011). Skriving i fagene: viktig, riktig og nødvendig. I K. H. Flyum, \& F. Hertzberg (Red.), Skriv $i$ alle fag! Argumentasjon og kildebruk $i$ videregående skole (s. 9-20). Oslo: Universitetsforlaget.

Hopper, P. J. (1982). Aspect between discourse and grammar: An introductory essay for the volume. I P. J. Hopper (Red.), Tense-Aspect: Between semantics and pragmatics (s. 3-19). Amsterdam: John Benjamins Publishing Company.

Hundal, A. K. (2017). Skriveutvikling på mellomtrinnet. En undersøkelse av sammenhengsmekanismer $i$ elevtekster og hvilke didaktiske forhold som bidrar til sammenheng $i$ tekst. (Doktoravhandling). Norges teknisknaturvitenskapelige universitet, Trondheim.

Kolstø, S. D., \& Knain, E. (Red.). (2011). Elever som forskere i naturfag. Oslo: Universitetsforlaget.

Morgan, C. (1998). Writing mathematically: The discourse of investigation. London: Falmer Press.

Ongstad, S. (1997). Sjanger, posisjonering og oppgaveideologier: Et teoretisk-empirisk bidrag til et tverrfaglig, semiotisk og didaktisk sjangerbegrep Norges teknisk-naturvitenskapelige universitet, Trondheim.

Ongstad, S. (2012). Rolle, stemme og posisjonering mellom gyldighet og relevans. I S. Matre, D. K. Sjøhelle, \& R. Solheim (Red.), Teorier om tekst $i$ møte med skolens lese- og skrivepraksiser (s. 33-48). Oslo: Universitetsforlaget.

Smidt, J. (2009). Developing discourse roles and positionings - an ecological theory of writing development. I R. Beard, D. Myhill, J. Riley, \& M. Nystrand (Red.), The SAGE handbook of writing development (s. 117-125). London: SAGE Publications Ltd.

Smidt, J. \& Evensen, L. S. (1991). Roller i relieff: skrivestrategier - tekster - lesestrategier, $n r 6$.

Solheim, R., \& Matre, S. (2014). Forventninger om skrivekompetanse: Perspektiver på skriving, skriveopplæring og vurdering i «Normprosjektet». Viden om lesning, 15, s. 76-88.

Timberlake, A. (1982). Invariance and the syntax of Russian aspect. I P. J. Hopper (Red.), Tense-Aspect: Between semantics and pragmatics (s. 305-331). Amsterdam: John Benjamins Publishing Company.

Tonne, I. (2001). Progressives in Norwegian and the theory of aspectuality (Doktoravhandling). UiO, Oslo.

Weber, M. (1949). The meaning of 'ethical neutrality' in sociology and economics I E. A. Shils, \& H. A. Finch (Red.), The methodology of the social sciences. New York: Free Press. 
Vedlegg 1. Skrivehjulet.
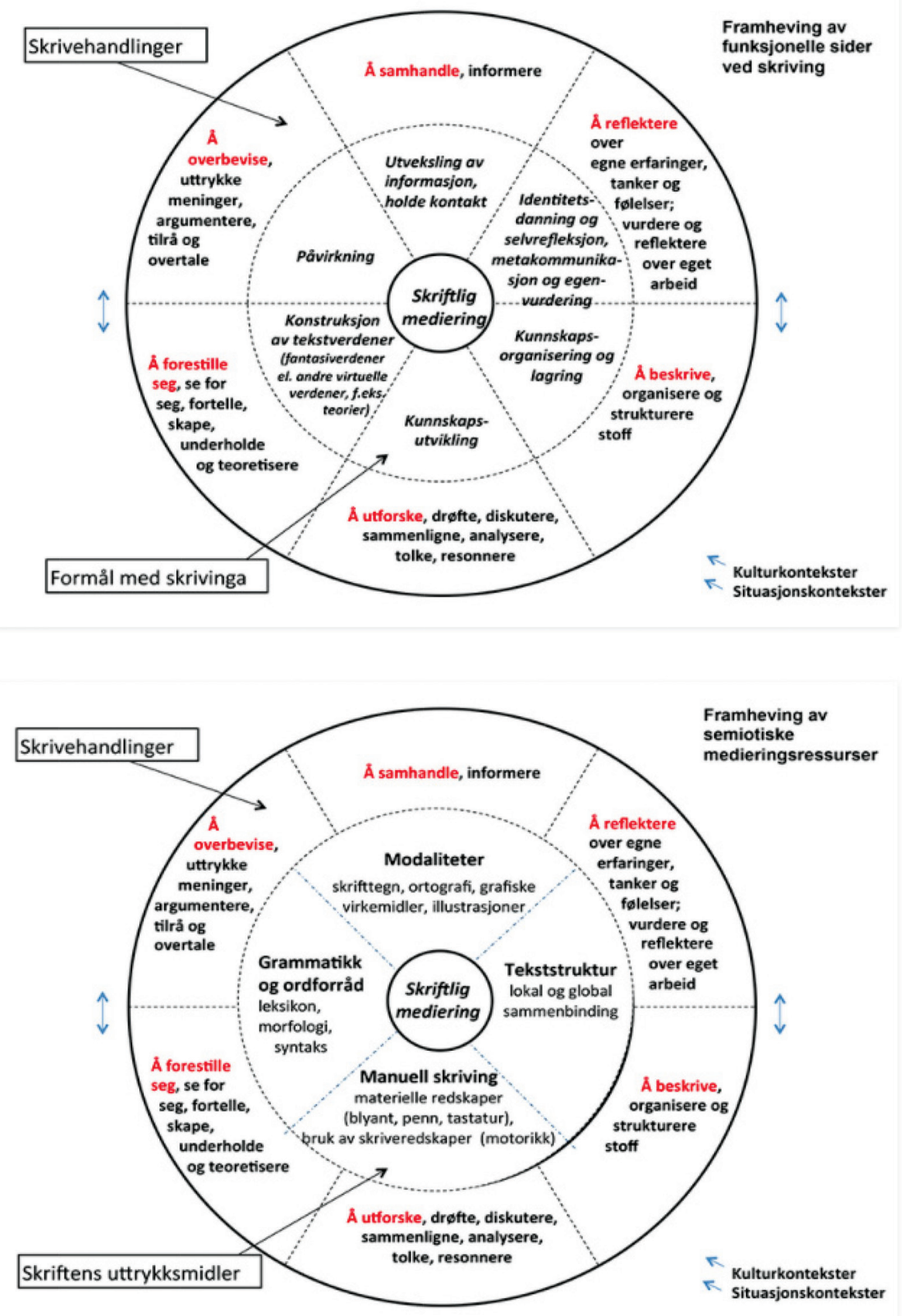


\section{S. Dagsland}

Vedlegg 2. Transkripsjon, Mortens tekst.

Det er litt forskjellig å regne med negative tall og med vanlige tall.

Med negative tall blir det slik:

$-5+-8=-\underline{\underline{13}}$ det blir en litt vrang måte å

å regne på.

Med positive tall blir det slik:

$5+8=\underline{13}$ det er lettere en med negative

tall. Det er det samme svaret, men med

negative tall blir det en opp ned tallinje. [pil til tallinje]

[tallinje midt på arket, med piler og streker tilhørende de to regnestykkene]

(negativt)

Du starter med -5

og skal + på -8

Da skal du legge

sammen de. Det blir 13,

men du må huske på

minus tegnet før svaret!

Jeg syntes det er lettere og regne med

Positive tall fordi, da er det ikke alle

De spesielle detaljene jeg må huske på. Son som

- før tallene under null. Det er bare lettere

med +!!!!!!!!!! (positivt)

Da er det bare å

plusse de to tallene.

Da skal det ikke være

noe minustegn foran svaret! 